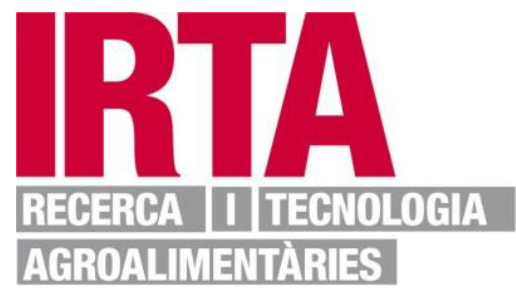

This document is a postprint version of an article published in Food and Chemical Toxicology (C) Elsevier after peer review. To access the final edited and published work see https://doi.org/10.1016/i.fct.2019.04.041 


\title{
Bioaccessibility of lipophilic and hydrophilic marine biotoxins in seafood: an in vitro digestion approach
}

Ricardo N. Alves ${ }^{1 *}$, Maria Rambla-Alegre ${ }^{2}$, Ana Catarina Braga ${ }^{1,3}$, Ana L. Maulvault ${ }^{1,4,5}$, Vera Barbosa, ${ }^{1}$ Mònica Campàs ${ }^{2}$, Laia Reverté ${ }^{2}$, Cintia Flores ${ }^{6}$, Josep Caixach ${ }^{6}$, Jane Kilcoyne $^{7}$, Pedro Reis Costa ${ }^{1,8}$, Jorge Diogène $^{2}$, António Marques ${ }^{1,4}$

${ }^{1}$ IPMA - Portuguese Institute of the Sea and Atmosphere, Av. Brasília, 1449-006 Lisbon, Portugal 2 IRTA, Ctra. Poble Nou, km. 5.5, 43540 Sant Carles de la Ràpita, Spain

${ }^{3}$ Department of Biology \& CESAM - Centre for Environmental and Marine Studies, University of Aveiro, 3810-193 Aveiro, Portugal

${ }^{4}$ Interdisciplinary Centre of Marine and Environmental Research (CIIMAR), University of Porto, Porto, Portugal

${ }^{5}$ MARE - Marine and Environmental Sciences Centre, Faculty of Sciences, University of Lisbon (FCUL), Lisboa, Portugal

${ }^{6}$ Mass Spectrometry Laboratory/Organic Pollutants, IDAEA-CSIC, Jordi Girona 18, 08034 Barcelona, Spain

${ }^{7}$ Marine Institute, Rinville, Oranmore, County Galway, Ireland

${ }^{8}$ CCMAR - Centre of Marine Sciences, University of Algarve, Campus of Gambelas, 8005-139 Faro, Portugal

${ }^{S}$ Current address: King Abdullah University of Science and Technology (KAUST), Red Sea Research Center (RSRC), Thuwal 23955-6900, Kingdom of Saudi Arabia.

\begin{abstract}
This study aimed to assess the bioaccessibility of different marine biotoxins in naturally contaminated shellfish and fish gonads using an in vitro digestion methodology. In general, hydrophilic toxins (domoic acid, paralytic shellfish poisoning toxins and tetrodotoxins) showed higher bioaccessibility than lipophilic ones (okadaic acid and azaspiracids). The bioaccessibility of toxins from the okadaic acid group ranged from 69 $\%$ (raw European razor clams) to $74 \%$ (raw donax clams). Regarding azaspiracids, $47 \%$ of the initial content was bioaccessible in steamed blue mussel. As for hydrophilic toxins,
\end{abstract}


$100 \%$ of the initial content was bioaccessible after digestion in raw shellfish and puffer fish gonads. The total tetrodotoxin bioaccessibility in puffer fish gonads decreased significantly after steaming. The profile of tetrodotoxins changed during the digestion process: TTX and 11-norTTX-6S-ol analogues decreased significantly after digestion, but the 5,6,11-trideoxy TTX analogue increased in both raw and steamed puffer fish gonads. These preliminary findings confirm the need to consider bioaccessibility data in future seafood risk assessment, as such information enables a more accurate and realistic estimation of potential seafood hazards, particularly in what concerns lipophilic toxins, therefore, constituting a crucial tool in the refinement of regulatory limits for the presence of biotoxins in seafood.

Keywords: seafood, bioaccessibility, okadaic acid, azaspiracids, domoic acid, PSP toxins, tetrodotoxins

\section{Introduction}

Some marine biotoxins are produced by specific harmful algae which may proliferate causing harmful algal blooms (HABs) under specific climatic and environmental conditions (Gerssen et al., 2010; Zingone and Enevoldsen, 2000). These toxins have been considered as a global problem, since they may represent a threat to human health, particularly due to human food-borne illnesses. In addition, HABs outbreaks can cause severe economic losses to the shellfish and fish industries due to the closure of harvesting areas (Berdalet et al., 2015; Visciano et al., 2016).

Some marine biotoxins present a complex chemical structure and toxicity, and may be classified in two large groups: lipophilic and hydrophilic toxins (Chen et al., 2016a; Gerssen et al., 2010; Toyofuku, 2006). A detailed description of the different 
marine biotoxins including their chemical structure, mode of action and respective poisoning symptoms was recently revised by Murk et al., (2019). Okadaic acid (OA) along with its analogues dinophysistoxins (DTX1 and DTX2) and their ester derivatives constituting the OA-group toxins are among the most common and abundant lipophilic biotoxins in European countries (Marr et al., 1992; Vale and Sampayo, 2002a), being responsible for diarrhetic shellfish poisoning (DSP) (EFSA, 2008a; Valdiglesias et al., 2013). Cases of DSP caused by OA-group toxins have been reported in Portugal, Italy, Spain, Norway and Ireland (Carmody et al., 1996; Ciminiello et al., 2014; Lee et al., 1989; Moita et al., 2016; Morono et al., 2003; Rodriguez et al., 2015). This health disorder is generally associated to blooms of dinoflagellates, particularly from the genus Dinophysis, but also from Prorocentrum and Phalachroma, which are ingested by shellfish species, including mussels, cockles, clams, scallops and oysters (Braga et al., 2016; Chen et al., 2016a; Gerssen et al., 2010; Manita et al., 2017; Torgersen et al., 2008; Vale and Sampayo, 2002b; Wu et al., 2015). Toxicological studies have revealed that OA-group toxins can have a carcinogenic, immunotoxic and neurotoxic effect in humans (Ferreiro et al., 2015; Valdiglesias et al., 2013).

Apart from the OA-group toxins, shellfish can also accumulate other lipophilic toxins, such as azaspiracids (AZAs) (Aasen et al., 2010; Salas et al., 2011; Tillmann et al., 2010). AZAs are a group of fast-acting polyether toxins produced by dinoflagellates from the genera Azadinium and Amphidoma. Symptoms caused by AZAs are similar to those elicited by OA-group toxins, and cases of AZAs-related human poisoning have been reported in Ireland, Portugal, Spain, France, Norway and Italy (Berdalet et al., 2015; Jauffrais et al., 2013; Percopo et al., 2013; Tillmann et al., 2010; Vale and Botana., 2008). Based on their frequent occurrence and toxicity to humans, the European Commission has set regulatory limits for the presence of both OA-group toxins and AZAs in seafood 
(i.e. $160 \mu \mathrm{g}$ OA or AZA equivalents per $\mathrm{kg}$ of shellfish meat; EFSA 2008a; 2008b; European Commission, 2004a).

The exposure to hydrophilic toxins also represents hazards to human health, including amnesic shellfish poisoning (ASP) and paralytic shellfish poisoning (PSP) (EFSA, 2009a; EFSA, 2009b; Gerssen et al., 2010; Quilliam and Wright, 1989). Domoic acid (DA) is a water-soluble cyclic amino acid produced by several species of diatoms from the genus Pseudo-nitzschia that structurally resembles the neurotransmitter glutamic acid. Thus, DA acts in the central nervous system by binding to glutamate receptors, leading to cell dysfunction due to the depolarization of neurons caused by the increase of calcium ions permeability (Berman and Murray, 1997). ASP symptoms include neurological and gastrointestinal disorders, involving short-term memory loss, incapacitating headaches, diarrhea, vomiting and in severe cases seizures, coma and death (EFSA, 2009a; Quilliam and Wright, 1989). Several cases of ASP outbreaks associated to the presence of DA have been reported around the world (Bates et al., 1989; Paredes et al., 2011; Pulido, 2008).

On the other hand, PSP is caused by neurotoxins, such as saxitoxin (STX), decarbamoylsaxitoxin (dcSTX), neosaxitoxin (Neo) and gonyautoxins 1-4 (GTXs). These toxins, also known as PSP toxins or PSTs, are produced by dinoflagellates from the genera Pyrodinium, Gymnodinium and Alexandrium. Generally, they act by blocking the voltage-gated sodium channels in both muscle and nerve cells (Deeds et al., 2008; Oshima et al., 1993; Wiese et al., 2010). Symptoms of PSP appear within 30 to 60 minutes after the ingestion of PSTs contaminated shellfish, and include vertigo, blocking of respiration, loss of coordination, facial numbness, vomiting, diarrhea and abdominal pain (reviewed by Ciminiello et al., 2014). PSP toxins have been detected in several coastal regions around the world, including the Atlantic coast from Norway to Portugal, and the 
Mediterranean region (Bernd and Bernd, 2008; Costa et al., 2015; Nakashima et al., 2004; Ngy et al., 2008). Therefore, given the risk to public health these two groups of toxins represent, the European legislation has set a maximum toxicity threshold of $20 \mathrm{mg}$ of DA per kg of shellfish meat and $800 \mu \mathrm{g}$ of PSP toxins (in STX equivalents) per $\mathrm{kg}$ of shellfish meat (European Commission, 2004a). Tetrodotoxin (TTX) is another potent neurotoxin that has a structure similar to STX, and blocks cell membranes' voltage gated sodium channels. The symptoms of TTX poisoning are often identical to those elicited by PSP toxins (How et al., 2003). The mode of action of TTX and STX is similar but with differences in the affinity of some subtypes of Nav channels. In particular at human nociceptive voltage-gated sodium channel (Nav1.7), as demonstrated by Walker et al (2012). The TTX group has more than 30 congeners and its poisoning is generally associated to the consumption of several puffer fish species, but it has also been detected in other marine organisms, including gastropods, bivalves, starfish and sea slugs (reviewed by Chen et al., 2016b). TTX is commonly found in different oceans including the South-East Asia region. Recently, based on the theory of "Lessepsian migration" of marine species from the Red Sea to the Mediterranean, puffer fish containing TTXs have also been observed in several locations in the Mediterranean Sea (Bentur et al., 2008). Recently, TTX has been detected in gastropods, mussels and oysters harvested in Portugal, Greece, the Netherlands and the United Kingdom (Nzoughet et al., 2013; Rodriguez et al., 2012; Silva et al., 2012). Currently, no regulatory limit has been set at European level for TTX, despite being a toxin of emerging concern (Ajani et al., 2017). In Europe, European Food Safety Authority (EFSA) has raised an opinion to establish 44 $\mu \mathrm{g}$ of TTX and/or the equivalent toxic amount of its analogues per $\mathrm{kg}$ shellfish meat as the possible regulatory level for TTXs (EFSA, 2017). In Japan, a maximum level of $2 \mathrm{mg}$ 
TTX. $\mathrm{kg}^{-1}$ has been established for the commercialization of puffer fish (Noguchi \& Ebesu, 2001).

To date, based on toxicological and risk assessment studies of marine toxins, regulatory limits are established expressing the maximum concentration of a given toxin in raw seafood (EFSA 2008a, 2008a, 2009a, 2009b, 2010). However, such estimations do not always reflect the amount of toxin that becomes available for absorption at the intestinal epithelium level, defined as compound bioaccessibility (Versantvoort et al., 2005). Several in vitro methods were developed to simulate the gastrointestinal digestion process in humans (Cardoso et al., 2015; Marques et al., 2011), being used to evaluate nutrients and contaminants' bioaccessibility in seafood (Alves et al., 2017, 2018; Cabanero et al., 2004, 2007; Maulvault et al., 2011). Yet, information about bioaccessibility of marine biotoxins after the human gastrointestinal digestion process is scarce. To the best of our knowledge, only two studies have assessed the bioaccessibility of marine toxins, both of them focusing on OA-group toxins (Braga et al., 2016; Manita et al., 2017), and only the later study considered the effect of shellfish cooking procedures on compound bioaccessibility (Manita et al., 2017). These studies reported not only the conversion of OA-group toxins into more toxic compounds during human digestion, but also a significant reduction of their bioaccessibility upon cooking seafood, reflecting the need to develop further studies covering bioaccessibility of other toxins and derivatives.

In this context, the aim of this study was to assess the bioaccessibility of a range of marine lipophilic and hydrophilic biotoxins (OA-group toxins, AZAs, DA, PSP toxins and TTXs) and their derivatives in naturally contaminated seafood species (blue mussels, donax clams, European razor clams, Mediterranean mussels, surf clams and puffer fish gonads), using an in vitro digestion methodology and accounting for the potential 
biotransformation of toxins throughout the digestive process. The effects of steaming on

TTXs bioaccessibility in puffer fish gonads was also studied.

\section{Materials and methods}

\subsection{Species sampling and sample preparation}

Twenty naturally contaminated seafood samples were obtained from laboratories conducting monitoring programs in different European countries. Samples included: i) one steamed sample of vacuum packed blue mussels (Mytilus edulis) from Ireland ii) eighteen shellfish samples collected from shellfish production areas along the Portuguese coast (i.e. European razor clams, Ensis arcuatus, $\mathrm{n}=4$; donax clams, Donax $s p ., \mathrm{n}=3$; Mediterranean mussels, Mytilus galloprovincialis, $\mathrm{n}=7$; cockles, Cerastoderma edule, $\mathrm{n}$ $=2$; and surf clams, Spisula solida, $\mathrm{n}=2$ and iii) pufferfish (Lagocephalus sceleratus; $\mathrm{n}$ =1) gonads from Denia (Spain). For each seafood species, origin, number of analyzed samples, number of specimens from each sample, and biotoxins group analyzed (target compounds were selected according to seafood species levels/profile of natural biotoxin contamination) are described in Table $\mathbf{1 .}$

Table 1.

Seafood species used for assessment of marine biotoxins bioaccessibility.

\begin{tabular}{|c|c|c|c|c|c|c|}
\hline Seafood & Species & Origin & $\mathbf{N}$ & $n$ & Raw/Steamed & $\begin{array}{c}\text { Marine } \\
\text { biotoxins } \\
\text { analysed }\end{array}$ \\
\hline Blue mussels & Mytilus edulis & Ireland & 1 & $\mathrm{n} / \mathrm{a}$ & Steamed & AZAs \\
\hline $\begin{array}{l}\text { European razor } \\
\text { clams }\end{array}$ & Ensis arcuatus & Portugal & 4 & 30 & Raw & OA-group \\
\hline Donax clam & Donax sp. & Portugal & 3 & 30 & Raw & OA-group \\
\hline \multirow{2}{*}{$\begin{array}{l}\text { Mediterranean } \\
\text { mussels }\end{array}$} & \multirow{2}{*}{$\begin{array}{c}\text { Mytilus } \\
\text { galloprovincialis }\end{array}$} & \multirow{2}{*}{ Portugal } & 3 & 30 & Raw & \\
\hline & & & 4 & 30 & Raw & $\mathrm{DA}$ \\
\hline Cockles & $\begin{array}{c}\text { Cerastoderma } \\
\text { edule }\end{array}$ & Portugal & 2 & 30 & Raw & DA \\
\hline Surf clams & Spisula solida & Portugal & 2 & 30 & Raw & $\mathrm{DA}$ \\
\hline $\begin{array}{c}\text { Pufferfish } \\
\text { gonads }\end{array}$ & $\begin{array}{c}\text { Lagocephalus } \\
\text { sceleratus }\end{array}$ & Spain & 1 & 1 & Raw/Steamed & TTXs \\
\hline
\end{tabular}


Thirty bivalve specimens per sample were removed from the shell, washed with running tap water to remove any salt water and sand residues, properly drained and homogenized with a blender. All shellfish samples were analyzed as a raw product, except mussels from Ireland (already provided as steamed product; specimens were heated in a water bath for 3 minutes). For the puffer fish sample, female gonads were selected as target tissue based on the fact that tissue has been previously described to accumulate high levels of TTX (Rambla-Alegre et al., 2017). Female gonads were dissected from puffer fish, then divided into two portions, one to be analysed as raw product and another to be analysed after steaming [i.e. steaming performed in an oven (Combi-Master CM 6, Rational GroßkÜcken Technik GmbH, Germany) at $105^{\circ} \mathrm{C}$ during $\left.10 \mathrm{~min}\right]$, in order to evaluate the effect of culinary treatment in TTX bioaccessibility. Raw and steamed gonads were subsequently homogenized with a grinder (Retasch Grindomix GM200, Germany) using polypropylene cups and stainless-steel knives at 10,000 g until complete visual disruption of the tissue. All homogenized shellfish and puffer fish gonads were stored at $-20{ }^{\circ} \mathrm{C}$ until further analyses.

\subsection{In vitro digestion model}

The bioaccessibility of OA-group toxins, AZAs, DA, PSP toxins in bivalves and TTXs in puffer fish gonad was assessed using an in vitro digestion methodology previously described by Versantvoort et al. (2005) and modified by Braga et al. (2016). Briefly, the simulated human digestion was performed in three different phases (oral, gastric and intestinal) using four digestive fluids (salivary, gastric, duodenal and bile), and each sample was digested in triplicate. For each sample, 1.5-2.0 g of shellfish/fish gonad samples was digested at $37{ }^{\circ} \mathrm{C}$ using a Rotary Tube Mixer with Disc (25 rpm; LSCI, Portugal). The simulated digestion was assessed using the following protocol: oral 
phase ( $4 \mathrm{~mL}$ of saliva fluid at $\mathrm{pH} 7.0 \pm 0.2 ; 5 \mathrm{~min})$, gastric phase ( $8 \mathrm{~mL}$ of gastric fluid at $\mathrm{pH} 2 \pm 0.2 ; 120 \mathrm{~min}$ ) and intestinal phase ( $8 \mathrm{~mL}$ of duodenal fluid and $4 \mathrm{~mL}$ of bile fluid at $\mathrm{pH} 7 \pm 0.2 ; 120 \mathrm{~min})$. Each digestion fluid was prepared just before starting the digestion protocol in order to avoid enzyme degradation/inhibition. At the end of the digestive process, digested samples were placed on ice to stop the digestion process, and centrifuged at $2,750 \times \mathrm{g}$ at $10{ }^{\circ} \mathrm{C}$ during $10 \mathrm{~min}$ to separate the bioaccessible (BIO) and non-bioaccessible (NBIO) fractions.

Considering that TTX analogues in puffer fish female gonads revealed extremely low concentrations during a preliminary bioaccessibility optimization assay, in this case, sub-samples (of both raw and steamed gonads) were also collected at the end of each digestive step, in order to evaluate the potential effects of each digestive phase (namely, $\mathrm{pH}$ conditions in the digestive fluids) on TTXs' bioaccessibility.

Digestion efficiency was confirmed by analysing total protein levels in samples before digestion (BD) and in both BIO and NBIO fractions, as detailed in Alves et al. (2017). Protein digestibility was always above $65 \%$.

\subsection{Toxins analysis}

Methodologies used to analyse each marine biotoxin group in $\mathrm{BD}, \mathrm{BIO}$ and NBIO fractions are described in Appendix A as supplementary data. Table 2 shows for each biotoxins group the methodology used, the limit of detection (LOD), the limit of quantification (LOQ), and the toxicity equivalency factors (TEFs) when applicable.

OA-group toxins and AZAs in BD samples and NBIO fractions were extracted following the Standardized Operating Procedure (SOP) of the European Reference Laboratory for Marine Biotoxins for the determination of marine lipophilic biotoxins in bivalve mollusks (EURLMB, 2015; Braga et al., 2016). In the case of BIO fractions, these 
toxins were extracted following Braga et al. (2016) and Manita et al. (2017). All fractions (BD, $\mathrm{BIO}$ and $\mathrm{NBIO}$ ) were analysed by liquid chromatography with tandem mass spectrometry detection (LC-MS/MS) following Braga et al. (2016) and García-Altares et al. (2013). DA extraction and quantification in BD samples and NBIO fractions was carried out by reversed phase high-performance liquid chromatography (RP-HPLC) using UV detection (EURLMB, 2008), following the EU Harmonised Standard Operating Procedure for determination of domoic acid in shellfish and finfish, modified by Vale \& Sampayo (2001). In the case of the BIO samples, fractions were extracted and determined following the same EURLMB, (2008) protocol, with minor modifications. PSP toxins extraction and determination in BD samples and in NBIO fractions were performed according to the AOAC Official Method 2005.06 (the so-called Lawrence method) modified by Costa et al. (2014), and BIO fractions were analysed by liquid chromatography and fluorescence detection (LC-FLD) as described in the official method (AOAC Official Method 2005.06). The extraction of TTXs in the BD samples and NBIO fractions of puffer fish gonads was performed following the protocol previously described by Reverté et al. (2015) for puffer fish tissues. For BIO samples, analyses were performed after filtration by nylon $0.2 \mu \mathrm{m}$. All three fractions (BD, BIO and NBIO) were analysed by LC-MS/MS detection, following the protocol previously described in detail by Rambla-Alegre et al. (2017) by a TSQ Quantum system (Thermo Fisher Scientific, Bremen, Germany).

Percentages of toxins in the bioaccessible fraction (\%) were calculated as follows: $\mathrm{BIO}$ x 100 / BD, where BIO corresponds to the toxin amount detected in the bioaccessible fraction and $\mathrm{BD}$ is the toxin amount detected in the sample before digestion. 
Table 2. Method description, limit of detection (LOD), limit of quantification (LOQ) and toxicity equivalency factors (TEFs) for each marine biotoxin group.

\begin{tabular}{|c|c|c|c|c|}
\hline & $\begin{array}{c}\text { Method } \\
\text { description }\end{array}$ & LOD & LOQ & TEFs (EFSA) \\
\hline $\begin{array}{l}\text { Okadaic Acid - group } \\
\text { (OA-group) toxins }\end{array}$ & $\begin{array}{l}\text { SOP for lipophilic } \\
\text { toxins from } \\
\text { EURLMB, } 2015\end{array}$ & $\begin{array}{c}\text { OA - } 15 \mu \mathrm{g} \cdot \mathrm{kg}^{-1} \\
\text { DTX1 - } 12 \mu \mathrm{g} \cdot \mathrm{kg}^{-1} \\
\text { DXT2 - } 12 \mu \mathrm{g} \cdot \mathrm{kg}^{-1}\end{array}$ & $\begin{array}{l}\text { OA - } 40 \mu \mathrm{g} \cdot \mathrm{kg}^{-1} \\
\text { DTX1 - } 40 \mu \mathrm{g} \cdot \mathrm{kg}^{-1} \\
\text { DXT2 - } 40 \mu \mathrm{g} \cdot \mathrm{kg}^{-1}\end{array}$ & $\begin{array}{c}\mathrm{OA}=1 \\
\text { DTX1=1 } \\
\text { DTX2 }=0.6\end{array}$ \\
\hline Azaspiracids (AZAs) & $\begin{array}{l}\text { SOP for lipophilic } \\
\text { toxins from } \\
\text { EURLMB, 2015 }\end{array}$ & $\begin{array}{l}\text { AZA1 - } 9 \mu \mathrm{g} \cdot \mathrm{kg}^{-1} \\
\text { AZA2 - } 9 \mu \mathrm{g} \cdot \mathrm{kg}^{-1} \\
\text { AZA3 - } 12 \mu \mathrm{g} \cdot \mathrm{kg}^{-1}\end{array}$ & $\begin{array}{l}\text { AZA1 - } 30 \mu \mathrm{g} \cdot \mathrm{kg}^{-1} \\
\text { AZA2 - } 30 \mu \mathrm{g} \cdot \mathrm{kg}^{-1} \\
\text { AZA3 - } 40 \mu \mathrm{g} \cdot \mathrm{kg}^{-1}\end{array}$ & - \\
\hline Domoic acid (DA) & $\begin{array}{l}\text { EU SOP for ASP } \\
\text { toxins, EURLMB, } \\
2008\end{array}$ & $\mathrm{DA}-0.7 \mu \mathrm{g} \cdot \mathrm{kg}^{-1}$ & $\mathrm{DA}-2 \mu \mathrm{g} \cdot \mathrm{kg}^{-1}$ & - \\
\hline $\begin{array}{l}\text { Paralytic shellfish } \\
\text { poisoning toxins } \\
\text { (PSP toxins) }\end{array}$ & $\begin{array}{l}\text { AOAC Official } \\
\text { Method 2005.06 }\end{array}$ & $\begin{array}{c}\text { STX - } 12 \mu \mathrm{g} \cdot \mathrm{kg}^{-1} \\
\text { dcSTX - } 11 \mu \mathrm{g} \cdot \mathrm{kg}^{-1} \\
\text { C1+2 - } 76 \mu \mathrm{g} \cdot \mathrm{kg}^{-1} \\
\text { dcGTX2+3 - 62 } \mu \mathrm{g} \cdot \mathrm{kg}^{-} \\
{ }^{1} \text { GTX2+3 - } 14 \mu \mathrm{g} \cdot \mathrm{kg}^{-1} \\
\text { GTX5 - } 13 \mu \mathrm{g} \cdot \mathrm{kg}^{-1}\end{array}$ & $\begin{array}{c}\text { STX - 36 } \mu \mathrm{g} \cdot \mathrm{kg}^{-1} \\
\text { dcSTX - 32 } \mu \mathrm{g} \cdot \mathrm{kg}^{-1} \\
\text { C1+2 - 228 } \mu \mathrm{g} \cdot \mathrm{kg}^{-1} \\
\text { dcGTX2+3 - } 187 \mu \mathrm{g} \cdot \mathrm{kg}^{-1} \\
\text { GTX2+3 - 59 } \mu \mathrm{g} \cdot \mathrm{kg}^{-} \\
{ }^{1} \mathrm{GTX} 5-57 \mu \mathrm{g} \cdot \mathrm{kg}^{-1}\end{array}$ & $\begin{array}{c}\text { STX }=1 \\
\text { dcSTX }=1 \\
\text { C1 } 1+2=0.1 \\
\text { dcGTX2 }+3=0.4 \\
\text { GTX2+3 }=0.6 \\
\text { GTX5 }=0.1\end{array}$ \\
\hline Tetrodotoxins (TTXs) & $\begin{array}{c}\text { Rambla-Alegre et al., } \\
2017 \\
\end{array}$ & TTX $-0.05 \mathrm{mg} \cdot \mathrm{kg}^{-1}$ & TTX $-0.1 \mathrm{mg} \cdot \mathrm{kg}^{-1}$ & - \\
\hline
\end{tabular}

\subsection{Statistics}

For both lipophilic and hydrophilic toxins groups, differences in bioaccessibility between seafood species were analysed by one-way analysis of variance (ANOVA) with the significance level set at 5\%. Tukey's post-hoc test was used for pair wise multiple comparisons. Prior to ANOVA analysis, normality and variance homogeneity were checked (SigmaPlot v10.0, Systat software, Inc., CA, USA). For each toxin group, differences in the toxin molar fractions between $\mathrm{BD}$ and $\mathrm{BIO}$ fractions were evaluated by t-student test with the significance level set at $5 \%$.

\section{Results}

\subsection{Baseline levels of lipophilic and hydrophilic toxins in seafood}

Toxicity levels for OA-group toxins and AZAs are presented in Table 3. OAgroup toxicity ranged from 116 to $231 \mu \mathrm{g} \mathrm{OA}$ eq. $\mathrm{kg}^{-1}$ in raw donax clams and from 93 to $254 \mu \mathrm{g}$ OA eq. $\mathrm{kg}^{-1}$ in raw European razor clams. The steamed mussel sample was naturally contaminated with high levels of AZAs (i.e. 12,529 $\mu$ g AZA eq.kg-1) (Table 3). 
The hydrophilic toxin DA was detected in mussels, cockles and surf clams. The highest (68 $\mathrm{mg} \mathrm{DA} \mathrm{kg}^{-1}$ ) and lowest (17 $\mathrm{mg} \mathrm{DA} \mathrm{kg}^{-1}$ ) DA concentrations were recorded in mussel samples. In cockles and surf clams, the highest DA levels were $56 \mathrm{mg} \mathrm{DA} \mathrm{kg}^{-1}$ and $66 \mathrm{mg}$ DA kg-1 ${ }^{-1}$ respectively (Table 3).

Toxicity levels of PSP toxins in mussels varied from 1,064 to 1,922 $\mu \mathrm{g}$ STX eq. $\mathrm{kg}^{-1}$ (Table 3). All samples analysed were above the maximum permitted level (MPL) of $800 \mu \mathrm{g}$ of PSP toxins equivalents per kg of shellfish meat. TTXs levels in raw and steamed puffer fish gonads were 141 and $213 \sum \mathrm{mg}$ TTXs.kg ${ }^{-1}$, respectively (Table 3).

Table 3. Lipophilic (OA-group toxins, AZAs) and hydrophilic (DA, PSP toxins, TTXs) marine toxins in seafood samples. Concentrations for OA-group toxins, AZAs and PSP toxins were based on toxicity equivalency factors (TEFs). Concentrations for TTXs were the sum of individual TTX and TTX analogues.

\begin{tabular}{|c|c|c|}
\hline & & Toxin concentration \\
\hline \multirow{10}{*}{$\begin{array}{l}\text { Lipophilic } \\
\text { toxins }\end{array}$} & Okadaic Acid - group (OA-group) toxins & $\mu \mathrm{g} \mathrm{OA} \mathrm{eq.} \mathrm{kg}^{-1}$ \\
\hline & \multirow{3}{*}{ Donax clam raw } & 231 \\
\hline & & 116 \\
\hline & & 203 \\
\hline & \multirow{4}{*}{ European razor clam raw } & 93 \\
\hline & & 170 \\
\hline & & 103 \\
\hline & & 254 \\
\hline & Azaspiracids (AZAs) & $\mu \mathrm{g}$ AZA eq. $\mathrm{kg}^{-1}$ \\
\hline & Blue mussel steamed & 12,529 \\
\hline \multirow{9}{*}{$\begin{array}{c}\text { Hydrophilic } \\
\text { toxins }\end{array}$} & Domoic acid (DA) & mg DA kg-1 \\
\hline & \multirow{4}{*}{ Mediterranean mussel raw } & 32 \\
\hline & & 29 \\
\hline & & 68 \\
\hline & & 17 \\
\hline & \multirow{2}{*}{ Cockle raw } & 56 \\
\hline & & 48 \\
\hline & \multirow{2}{*}{ Surf clam raw } & 66 \\
\hline & & 65 \\
\hline
\end{tabular}




\begin{tabular}{cc}
\hline $\begin{array}{c}\text { Paralytic shellfish poisoning toxins } \\
\text { (PSP toxins) }\end{array}$ & $\boldsymbol{\mu g} \mathbf{S T X e q .} \mathbf{~ k g}^{-\mathbf{1}}$ \\
Mediterranean mussel raw & 1,922 \\
& 1,468 \\
Tetrodotoxins (TTXs) & 1,064 \\
Puffer fish gonad raw & $\sum \mathbf{m g} \mathbf{T T X s} \mathbf{~ k g}^{-1}$ \\
Puffer fish gonad steamed & 141 \\
\hline
\end{tabular}

\subsection{Bioaccessibility of marine toxins}

Figure 1 shows the total lipophilic (A) and hydrophilic (B) toxins bioaccessibility in seafood. In general, hydrophilic toxins showed higher bioaccessibility than the lipophilic ones. For OA-group toxins, high percentages of bioaccessibility were observed in both raw donax clam (74 \%) and razor clam (69\%). Azaspiracids in steamed mussels revealed low toxins' bioaccessibility $(47 \%, p<0.05)$, (Fig. 1A). In the case of hydrophilic toxins, high bioaccessibility was observed for DA and PSP toxins in raw shellfish, as well as, for total TTX in raw gonad (107\%). DA and PSP toxins were $100 \%$ bioaccessible in Mediterranean mussels, cockles and surf clams ( $p>0.05$; Fig. 1B). In puffer fish gonads, total TTX bioaccessibility decreased significantly after steaming (59\%; $p<0.05)$, (Fig.1B). When analysing individual TTX analogues, different bioaccessibilities were observed: while for some TTX analogues the bioaccessibility increased, interestingly, for parent TTX the bioaccessibility decreased to regardless of the processing (15\% for raw and $14 \%$ for steamed). 
A) Lipophilic

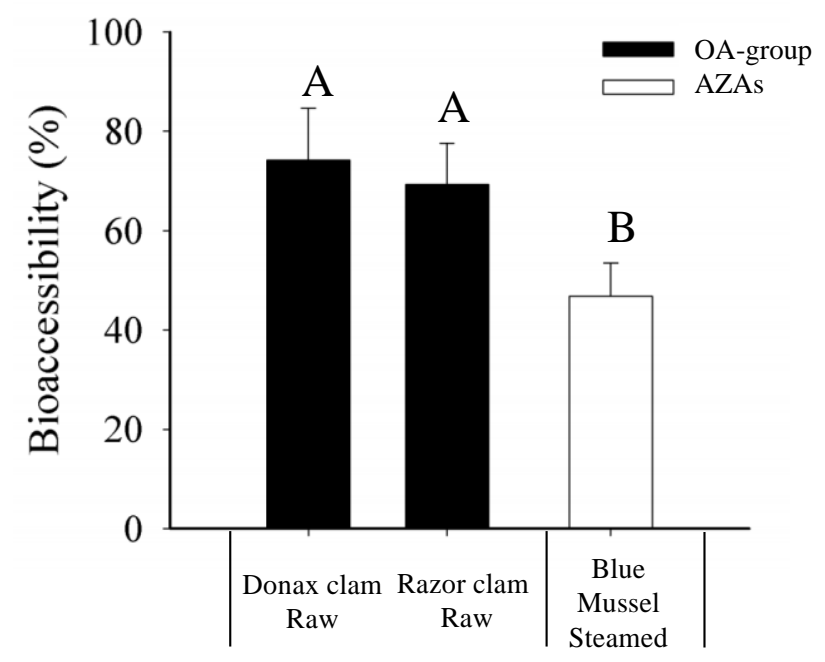

B) Hydrophilic

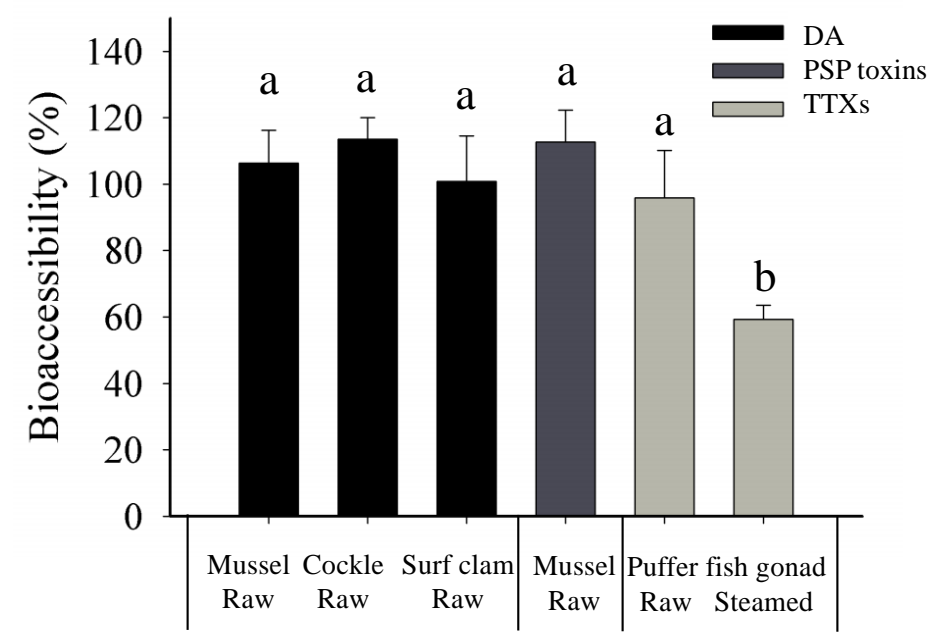

Fig.1. Bioaccessibility (\%, average \pm standard deviation) of (A) lipophilic (OA-group, AZAs) and (B) hydrophilic toxins in seafood (DA, PSP toxins, TTXs). A - Uppercase letters represent differences in lipophilic toxins bioaccessibility between seafood species (ANOVA, $p<0.05$ ). B - Lowercase letters represent differences in hydrophilic toxins bioaccessibility between seafood species (ANOVA, $p<0.05$ ).

The profile of the toxins in samples before (BD) and after the in vitro digestion (BIO) is shown in Fig. 2. Profile of OA-toxins group varied between shellfish species. OA-toxins group profile in donax clams was characterized by the following analogues: free DTX2 $(35 \%)>$ esterified OA $(29 \%)>$ free OA $(25 \%)>$ esterified DTX2 $(11 \%)$. Razor clams had a toxin profile mainly composed by esterified OA (84\%). No significant 
changes in toxins profile were observed after in vitro digestion neither in donax clams and nor in razor clams (t-student, $p>0.05)$, (Fig. 2A). In the case of AZA, toxins mass fractions were maintained after digestion (t-student, $p>0.05$ ), and varied according to the following order: AZA1 > AZA3 > AZA2 (Fig. 2B).

Figure2C shows the PSP toxins profile in raw mussels, and the most abundant forms in this sample were saxitoxins analogues, such as $\mathrm{N}$-sulfocarbamoyl toxins $\mathrm{C} 1+2$ (74\%) and GTX5 (21\%), followed by decarbamoyl toxins (dcGTX2+3, dcSTX) and gonyautoxins (GTX2+3). Saxitoxin (STX) was not detected in the mussel samples. No significant changes were observed in toxins profiles between BD and BIO fractions $(p>$ 0.05), (Fig. 2C). Out of the nine TTX analogues analysed, 5,6,11-trideoxyTTX was the most abundant in the puffer fish gonads (raw - $67 \%$, steamed $-81 \%$ ). On the other hand, TTX (raw - $16 \%$, steamed - $9 \%$ ) and 11-norTTX-6S-ol (raw - $12 \%$, steamed - $6 \%$ ) were present at much lower concentrations. TTX and 11-norTTX-6S-ol analogues decreased significantly after digestion ( $\mathrm{t}$-student, $p<0.05$ ), nevertheless the 5,6,11trideoxy TTX analogue showed a significant increase $(p<0.05)$ in both raw and steamed puffer fish gonads (Fig. 2D).

Taking into account the bioaccessibility percentage of the parent TTX toxin in raw pufferfish gonad (20\% in the whole in vitro digestion model; data not shown), TTX bioaccessibility was evaluated throughout the in vitro digestion process (oral phase $\mathrm{pH} 7$, gastric phase $\mathrm{pH} 2$ and intestinal phase $\mathrm{pH}$ 7). Percentages of $\mathrm{BIO}$ and NBIO fractions are presented in Fig. 3. In both oral and intestinal phases only around $20 \%$ of TTX was bioaccessible. No significant differences were observed in the TTX concentrations before and after the gastric phase. The same trend of bioaccessibility percentages was observed for the other TTX analogues 5,6,11-trideoxyTTX, 4-epiTTX and 11-norTTX-6S-ol (data not shown). 

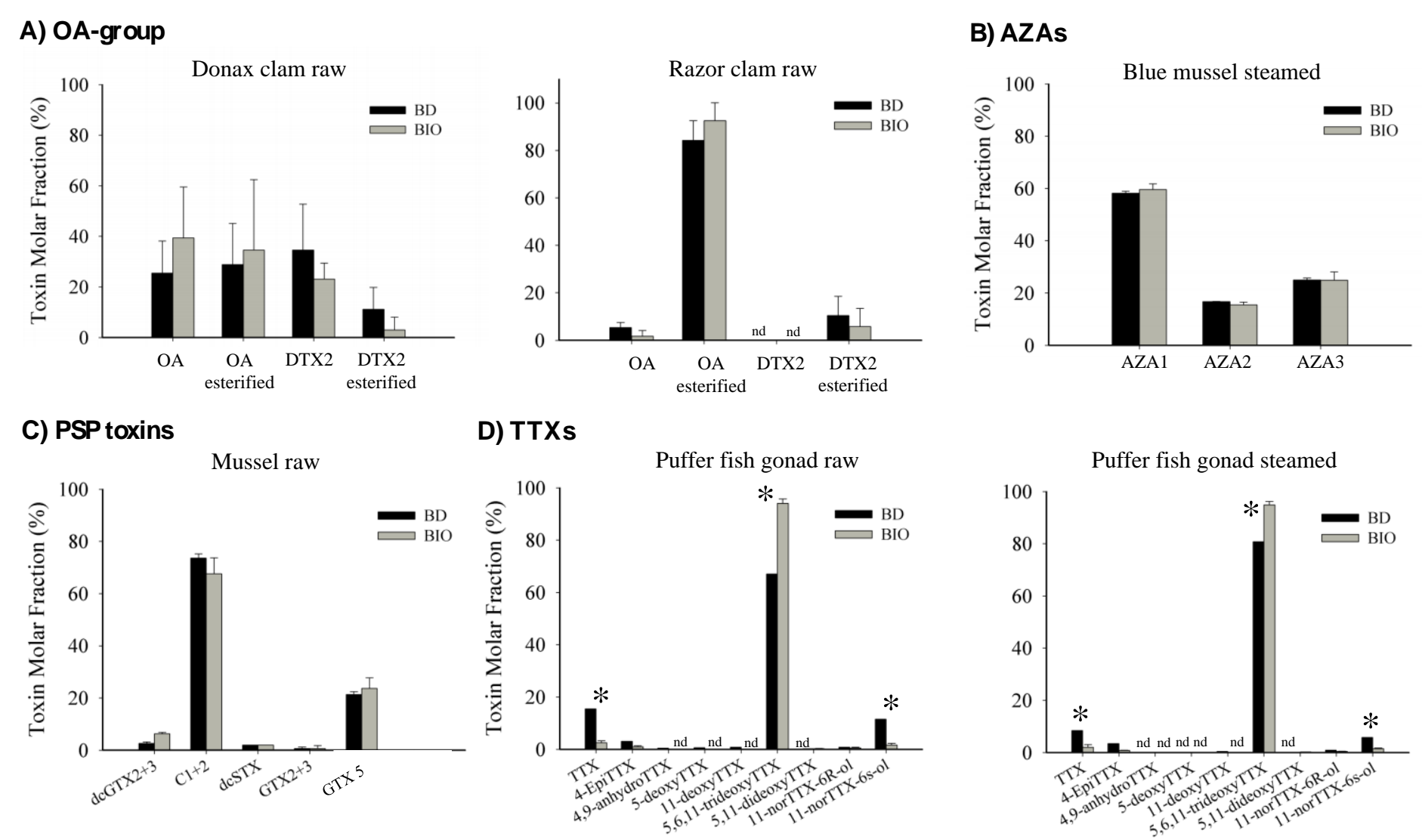

Fig. 2. Profile of lipophilic (A-B) and hydrophilic (C-D) marine toxins (\%, average \pm standard deviation) in seafood samples before digestion (BD) and in the bioaccessible fractions (BIO). A) OA-group toxins in donax clams and European razor clams and in steamed blue mussel; B) AZAs group in steamed blue mussel; C) PSP toxins in Mediterranean mussels and D) TTXs in puffer fish gonads. Asterisk (*) represent differences for the toxins profile between BD and BIO (t-student, $\mathrm{p}<0.05)$. 


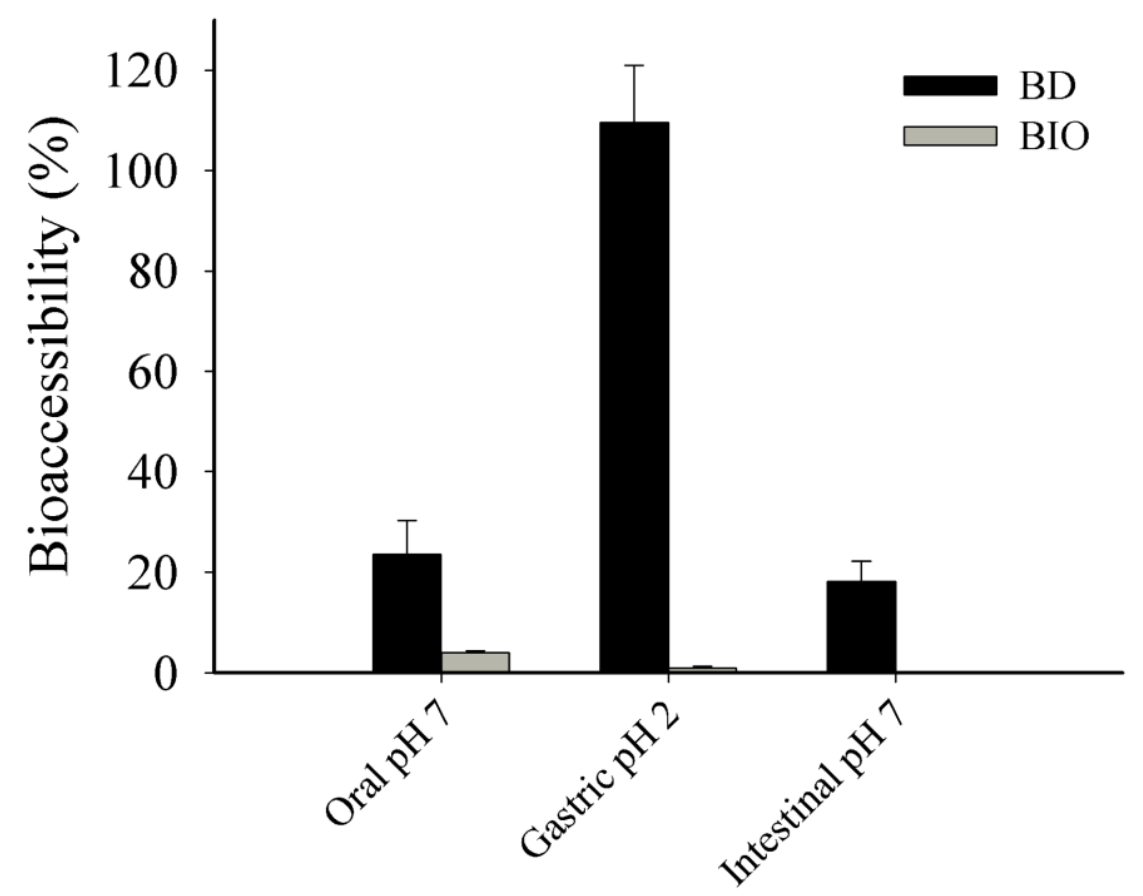

Fig. 3. Bioaccessibility (\%) of parent TTX in pufferfish gonads during the digestion phases (oral, gastric and intestinal) in bioaccessible (BIO) and non-bioaccessible (NBIO) fractions.

\section{Discussion}

\subsection{Occurrence and profiles of lipophilic and hydrophilic toxins in seafood}

The production of toxins by phytoplankton and or symbiotic bacteria, as well as their accumulation in bivalve and fish species has been well recognized throughout European countries (Costa et al., 2017; McNamee et al., 2016). Yet, the consumption of seafood contaminated with these toxins leads to known food-borne human diseases, which represents the main health hazard associated with marine toxins (Berdalet et al., 2015).

Two lipophilic toxins groups were studied, i.e. OA-group toxins and AZAs. In the present study, five out of eight shellfish samples showed OA levels at concentrations above the maximum permitted level (MPL) of $160 \mu \mathrm{g}$ OA eq. $\mathrm{kg}^{-1}$ (European 
Commission, 2004a), therefore, representing a risk for seafood consumers. The OA toxins concentration obtained in this study in donax clams and European razor clams was within the range of values previously reported for harvested natural contaminated shellfish (between 44 and $892 \mu$ g OA eq. kg-1 ; e.g. Rodríguez et al., 2015; Braga et al., 2016). For example, donax clams collected in Portuguese coast during 2014 showed an OA toxicity ranging between 229 and 395 OA eq. $\mathrm{kg}^{-1}$ (Braga et al., 2016). In shellfish from Galicia coast, total OA concentration showed a high variability between samples (44 up to 892 $\mu \mathrm{g}$ OA eq. $\mathrm{kg}^{-1}$ ) (Rodríguez et al., 2015). In Europe, OA and DTX2 are most commonly found in free or esterified forms, though the proportion of these compounds may greatly vary between samples. Moreover, the fact that DTX1 was not detected in any sample is in agreement with previous findings (Johnson et al., 2016; Rodríguez et al., 2015; Vale \& Sampayo, 2002a).

Differences in the OA-group toxins profile were observed between shellfish species, showing the following profiles, higher levels of esterified DTX2 (razor clam) and equal proportions of both free and esterified OA (donax clam). Such results were not surprising as OA-group toxins profile can change according to algae and shellfish species, sampling location and seasonality (EFSA, 2008a; Moita et al., 2016; Yasumoto et al., 1985). For example, three different OA-group toxins profiles were identified in mussels (Mytilus sp.) from Great Britain collected between 2011 and 2015. Mussels were predominantly composed by free OA, free DTX2 or even esterified OA as observed in mussel samples from that study (Johnson et al., 2016). As previously reported, mussels and donax clams have low ability to efficiently biotransform OA into fatty acid ester derivatives compared to razor clams (Rossignoli et al., 2011; Vale and Sampayo, 2002b).

Although OA group usually predominate (in terms of quantity and frequency) within the lipophilic toxins, co-occurrence with other lipophilic toxins such as AZAs can 
occur (Regueiro et al., 2011; Villar-González et al., 2007), as observed in the steamed blue mussel sample. The AZAs content in the steamed mussel sample from Ireland was above the maximum MPL of $160 \mu \mathrm{g}$ AZA eq. $\mathrm{kg}^{-1}$ (EFSA, 2008b). This result matched the previously reported maximum AZA levels in raw blue mussels from Ireland $(8,970$ $\mu \mathrm{g}$ AZA1 eq. $\mathrm{kg}^{-1}$ ) (Salas et al., 2011). Moreover, an increase in AZAs concentration in mussels after steaming was also expected due to the loss of water (Hess et al., 2005), and may justify the high toxicity observed in the present study for these toxins. Although AZAs have been identified in shellfish from several European countries, toxin levels were generally very low, therefore, suggesting reduced risks of human disease outbreaks due to azaspiracids poisoning (AZP) (Amzil et al., 2008; Bacchiocchi et al., 2015; Twiner et al., 2008). More than 10 AZA analogues have been reported in shellfish, but AZA1, AZA2 and AZA3 are the predominant analogues detected in European shellfish (James et al., 2002). Similarly, to the present study, James et al. (2005) reported the, overall, predominance of AZA1 toxin (50-65\%) over AZA2 (20-30\%) and AZA3 (5-20\%).

Three hydrophilic toxins groups were also investigated in this study, i.e. DA and PSP toxins in shellfish and TTX in fish. DA concentrations observed in the eight shellfish samples from the Portuguese coast were close or above the established DA MPL (20 mg $\mathrm{DA} \mathrm{kg}^{-1}$ ) (European Commission, 2004a, 2004b). Such variability, even within the same species, has also been reported in other studies (EFSA, 2009a; James et al., 2005; Ujević et al., 2010; Vale \& Sampayo, 2001). Unintended ingestion of PSP toxins is the main cause of PSP incidents (i.e. around 2,000 reported cases worldwide), often having devastating consequences. For instance, in the Philippines, between 1983 and 2002, more than 115 PSP cases resulted in death (Ching et al., 2015), mostly associated with STX and some GTX, showing severe toxicity. In our study, mussels from the Portuguese coast showed PSP toxins levels above the MPL for the safe consumption of shellfish (i.e. 800 
$\mu \mathrm{g}$ equiv. STX kg-1; European Commission, 2004a, 2004b). According to the EFSA, mussels seem to be the bivalve organisms that are mostly susceptible to PSP toxins contamination (EFSA, 2009b). Portugal and Spain have been considered two areas that are greatly affected by PSP toxins, with these toxins showing values as high as 67,616 and 40,800 $\mu \mathrm{g}$ STX equiv. $\mathrm{kg}^{-1}$ of shellfish meat, respectively (EFSA, 2009a). Additionally, results obtained in the present study are in accordance with previous PSP toxins occurrence in Iceland, Chile and New Zealand (Burrell et al., 2013; MacKenzie, 2014; Zamorano et al., 2013). Out of the several identified STX-like congeners, C1+2, GTX5 and the decarbamoyl toxins dcGTX2+3 and dcSTX represented more than $90 \%$ of the toxin profile detected in the Mediterranean mussel samples. Although they represent more than $90 \%$ of toxins profile in mussels and their presence is often associated with outbreaks of paralytic shellfish poisoning in Portugal, these toxins have been described to be moderately toxic to humans (Botelho et al., 2015; Costa et al., 2015; Etheridge, 2010; Negri et al., 2007).

TTX is considered to be one of the most dangerous and lethal toxin in the marine environment, and the number of poisoning cases in European countries is increasing (Fernández-Ortega et al., 2010). Presently, legislation in Europe establishes that poisonous fish of the family Tetraodontidae and products derived from them must not be placed on the markets (European Commission, 2004a, 2004b). So far, no regulatory limit has been established in the EU for the presence of this toxin in seafood, although EFSA has set a value of $44 \mathrm{ug} \cdot \mathrm{kg}^{-1}$ as a possible limit (EFSA, 2017). The levels obtained in the present study (raw and steamed gonads) were within the range of values previously reported for TTX (0.17-239.32 $\mathrm{mg} \mathrm{kg}^{-1}$ in gonads; Rambla-Alegre et al. 2017). Yet, these values are 10-fold above the Japanese acceptability criterion value of $2 \mathrm{mg}$ TTX equiv. $\mathrm{kg}^{-1}$ pufferfish tissue for human consumption (Noguchi \& Ebesu, 2001). 
In the current study, parent TTX represented less than $16 \%$ of the total TTX toxins. More than 30 congeners of TTX with different levels toxicity have been isolated and identified in marine organisms to date (reviewed by Bane et al., 2014). The 5,6,11trideoxy TTX was the predominant TTX congener observed in both raw (molar fraction, $67 \%$ ) and steamed (molar fraction, $81 \%$ ) puffer fish gonad. In fact, 5,6,11-trideoxy TTX was reported as the predominant congener in Lagocephalus sceleratus and other fish species, such as Fugu pardalis, Fugu niphobles and Tetraodon nigroviridis (Jang et al., 2006, 2010; Rodríguez et al., 2012). In addition, 5,6,11-trideoxy TTX is considered to be less toxic compared to the TTX parental toxin, given the fact that this derivative exhibits a lower number of hydroxyl groups (Yotsu-Yamashita, 2007).

\subsection{Toxins bioaccessibility and changes in toxins profile after in vitro digestion}

So far, information on marine toxins' bioaccessibility is scarce, and only data on OA-group toxins has been previously reported (Braga et al., 2016; Manita et al., 2017). To the best of our knowledge, this is the first study reporting bioaccessibility percentages for AZAs, DA, PSP toxins and TTXs in seafood.

Matching the present results, bioaccessibility of OA, DTX2 and their ester derivatives has been previously reported in raw mussels (87\%), donax clams (75\%) and cockles (59\%), (Braga et al., 2016; Manita et al., 2017). The bioaccessibility value in European razor clams in the present study was closer to the one observed in donax clams, despite the toxin profiles in the two species being remarkably different, with European razor clams exhibiting a profile where over $80 \%$ of the toxin was esterified, and donax clams profile reaching only $40 \%$. Little is known about the absorption and metabolism of AZAs in mammals. The results obtained in the present study show that AZAs bioaccessibility in steamed mussel was around 45\%, as observed for other lipophilic 
toxins in steamed shellfish (Manita et al. 2017). Our findings are in accordance with previous observations done by Kilcoyne et al. (2014), that reported AZAs bioaccessibility values between $30-54 \%$ in raw mussel. However, only $10 \%$ of bioaccessible AZAs was observed in the same steamed samples. These authors suggested that thermal denaturation of proteins in mussel tissues occurred and this may have been the main reason for such low bioaccessibility, as AZAs seem to be weakly bound to $45 \mathrm{kDa}$ proteins. This difference between our results and those observed by Kilcoyne et al. (2014) can be explained by the use of different in vitro digestion protocols. In contrast to the OA-group toxins, no conversion between AZA analogues was observed during the in vitro digestion. Nevertheless, it has been suggested in an in vivo experiment with mini pigs orally exposed to AZAs that the metabolism of AZAs can occur during digestion (Geraghty et al., 2014).

To our knowledge, this is the first study reporting hydrophilic toxins (DA, PSP toxins) bioaccessibility, and results showed that almost $100 \%$ of toxins were available to be absorbed by the gastrointestinal tract after digestion. This complete bioaccessibility was not surprising due the hydrophilic nature of these toxins, as it has been reported that less hydrophobic compounds may be more easily transferred to the bioaccessible digestion fluids during digestion (Alves et al., 2017). No conversion between PSP analogues was observed after the digestion process. Some studies revealed that PSP toxins metabolism occurs in humans during digestion. Hepatic conversion of STX and GTX3/GTX2 epimers into neoSTX or GTX4/GTX1 epimers, respectively, by oxidation and glucuronidation of PSP toxins can occur (García et al., 2004, 2009, 2010). However, these PSP toxins analogues were not the most abundant in the toxins' profile of mussel samples.

TTXs, which are $\mathrm{Na}^{+}$channel blockers (Lee and Ruben, 2008), also showed high bioaccessibility (100\%, for raw and $59 \%$ for steamed), but parent TTX showed very low 
bioaccessible values (14-15\%). This could be due to the digestion conditions carried out during the in vitro bioaccessibility process. In this work, the three main digestive steps were individually evaluated in order to better understand this biochemical mechanism. The high TTX bioaccessibility observed (around $100 \%$ ) at the end of the gastric step demonstrates that the decrease in the $\mathrm{pH}$ during this phase is not the main factor for the low TTX bioaccessible values observed at the end of the digestion process. In addition, at the gastric phase, a higher $\mathrm{pH}$ was tested, in order to evaluate the stability of the TTX regarding $\mathrm{pH}$ conditions. A bioaccessible percentage of $37 \%$ was obtained at $\mathrm{pH} 7$ (data not shown), while around $100 \%$ was observed at $\mathrm{pH} 2$, showing the importance of the $\mathrm{pH}$ in the bioaccessibility study. The decrease in the TTX bioaccessibility should occur somewhere during the intestinal phase, and TTX analogues conversion during this step can be a possible explanation. 5,6,11-TrideoxyTTX, 11-norTTX-(S/R)-ol and 4-epiTTX were the main analogues of TTX observed in the BIO and NBIO fractions, with the latter compound being chemically interchangeable with TTX. Some conversion in the bioaccessible fractions was observed in TTX analogues, resulting in TTX decreases (2.5\%) and 5,6,11-trideoxyTTX increases (94\%). This could be attributed to the dehydrogenation of some hydroxyl groups during the digestion process (YotsuYamashita et al. 1995). The biosynthetic and metabolic pathways of TTX remain to be elucidated. Yotsu-Yamashita et al. 2013 described the oxidation process from 5,6,11trideoxyTTX to TTX where 5,6,11-trideoxyTTX is first oxidized to 5,11-dideoxyTTX, which would be oxidized to both 5-deoxyTTX and 11-deoxyTTX. These monodeoxy TTXs are predicted to be the exact precursors of TTX (Yotsu-Yamashita et al. 2013). 


\section{Conclusions}

The current study provided new insights on marine biotoxins that may be of interest to evaluate potential dietary exposure to some marine toxins through the consumption of seafood. The bioaccessibility of toxins from the okadaic acid group ranged from 69 up to $74 \%$. Regarding azaspiracids, $47 \%$ of the initial content was bioaccessible in steamed blue mussel after the in vitro digestion. Unlike lipophilic OAgroup toxins and AZAs, after in vitro digestion, the initial content of hydrophilic toxins (DA, PSP toxins and total TTXs) was almost totally bioaccessible for absorption by the human intestine epithelia. In puffer fish gonads, steaming significantly reduced the bioaccessibility of total TTXs. Hence, these results raise the interest for conducting future studies on the effects of different culinary treatments, including steaming, in other toxins groups. The present data also provided an insight on the possible transformation of some toxins after digestion, including those from TTX analogues, but the mechanisms underlying this transformation still remain to be elucidated. In future studies, it will also be interesting to evaluate the role of the gastrointestinal tract microflora in the biotransformation of toxins analogues.

As for lipophilic toxins, the present bioaccessibility results suggest that previous data on the exposure to these toxins may be overestimated. In contrast, for the majority of the analysed hydrophilic toxins, the total toxin concentration detected in seafood can be considered as the amount of the toxin that will become available for absorption after digestion. In this way, these preliminary results prove that compound bioaccessibility can be a powerful tool towards a more accurate evaluation of risks and benefits associated with seafood consumption, and call for the need to define new and more realistic guidelines and regulations for the presence of marine toxins in seafood. Finally, taking into consideration the limitations of the present study (i.e. number of seafood 
species/samples analysed), further studies are urgently required to diversify and increase data robustness on toxins' bioaccessibility.

\section{Acknowledgements}

The research leading to these results has received funding from the European Union Seventh Framework Programme (FP7/2007-2013) under the ECsafeSEAFOOD project (grant agreement $n^{\circ} 311820$ ) and through the European Regional Development Fund. IRTA members acknowledge support from CERCA Programme/Generalitat de Catalunya. L.R. acknowledges a scholarship from the ECsafeSEAFOOD project. Ana C. Braga has a Doctoral Grant (PD/BD/113484/2015) from the Portuguese Science and Technology Foundation (FCT), whereas Antonio Marques and Pedro R. Costa are supported through the FCT Investigator program (IF). Lagocephalus sceleratus was kindly provided by Andrés Izquierdo-Muñoz from Centro de Investigación Marina de Santa Pola (CIMA) (Spain).

\section{References}

Aasen, J.A.B., Espenes, A., Hess, P., \& Aune, T. (2010). Sub-lethal dosing of azaspiracid1 in female NMRI mice. Toxicon, 56, 1419-1425.

Ajani, P., Harwood, D.T., Murray, \& S.A. (2017). Recent Trends in Marine Phycotoxins from Australian Coastal Waters, Marine Drugs, 15, 1-20.

Alves, R.N., Maulvault, A.L., Barbosa, V.L., Cunha, S., Kwadijk, C.J., Alvarez-Munoz, D., Rodriguez-Mozaz, S., Aznar-Alemany, O., Eljarrat, E., Barcelo, D., FernandezTejedor, M., Tediosi, A., \& Marques, A. (2017). Preliminary assessment on the 
bioaccessibility of contaminants of emerging concern in raw and cooked seafood, Food and chemical toxicology, 104, 69-78.

Alves, R.N., Maulvault, A.L., Barbosa, V.L., Fernandez-Tejedor, M., Tediosi, A., Kotterman, M., van den Heuvel, F. H. M., Robbens, J., Fernandes, J. O., Rasmussen, R. R., Sloth, J. J., \& Marques, A. (2018). Oral bioaccessibility of toxic and essential elements in raw and cooked commercial seafood species available in European markets, Food Chemistry, 267. 15-27.

Amzil, Z., Sibat, M., Royer, F., \& Savar, V. (2008). First report on azaspiracid and yessotoxin groups detection in French shellfish, Toxicon, 52(1), 39-48.

Anonymous (2005). AOAC Official method 2005.06 Quantitative determination of paralytic shellfish poisoning toxins in shellfish using pre-chromatographic oxidation and liquid chromatography with fluorescence detection. AOAC International, Gaithersburg.

Bacchiocchi, S., Siracusa, M., Ruzzi, A., Gorbi, S., Ercolessi, M., Cosentino, M. A., Ammazzalorso, P., \& Orletti, R. (2015). Two-year study of lipophilic marine toxin profile in mussels of the North-central Adriatic Sea: First report of azaspiracids in Mediterranean seafood, Toxicon, 108, 115-125.

Bane, V., Lehane, M., Dikshit, M., O'Riordan, A., \& Furey, A. (2014). Tetrodotoxin: chemistry, toxicity, source, distribution and detection, Toxins, 6(2), 693-755. 
Bates, S.S., Bird, C.J., Defreitas, A.S.W., Foxall, R., Gilgan, M., Hanic, L.A., Johnson, G.R., Mcculloch, A.W., Odense, P., Pocklington, R., Quilliam, M.A., Sim, P.G., Smith, J.C., Rao, D.V.S., Todd, E.C.D., Walter, J.A., \& Wright, J.L.C. (1989). Pennate Diatom Nitzschia pungens as the Primary Source of Domoic Acid, a Toxin in Shellfish from Eastern Prince Edward Island, Canada, Canadian Journal of Fisheries and Aquatic Sciences, 46, 1203-1215.

Berdalet, E., Fleming, L.E., Gowen, R., Davidson, K., Hess, P., Backer, L.C., Moore, S.K., Hoagland, P., \& Enevoldsen, H. (2015). Marine harmful algal blooms, human health and wellbeing: challenges and opportunities in the 21st century, Journal of the Marine Biological Association of the United Kingdom, 96, 61-91.

Berman, F.W., \& Murray, T.F. (1997). Domoic acid neurotoxicity in cultured cerebellar granule neurons is mediated predominantly by NMDA receptors that are activated as a consequence of excitatory amino acid release, Journal of neurochemistry, 69, 693-703.

Bernd, C., \& Bernd, B. (2008). Determination of marine biotoxins relevant for regulations: from the mouse bioassay to coupled LC-MS methods, Analytical and Bioanalytical Chemistry, 391, 117-134.

Blanco, J., Arevalo, F., Correa, J., Porro, M. C., Cabado, A. G., Vieites, J. M., \& Morono, A. (2015). Effect of the industrial steaming on the toxicity, estimated by LC-MS/MS, of mussels exposed for a long time to diarrhetic shellfish poisoning (DSP) toxins, Food Chemistry, 177, 240-247. 
Braga, A.C., Alves, R.N., Maulvault, A.L., Barbosa, V., Marques, A., \& Costa, P.R. (2016). In vitro bioaccessibility of the marine biotoxin okadaic acid in shellfish, Food and Chemical Toxicology, 89, 54-59.

Bentur, Y.; Ashkar, J.; Lurie, Y.; Levy, Y.; Azzam, Z.S.; Litmanovich, M.; Golik, M.; Gurevych, B.; Golani, D.; \& Eisenman, A. (2008). Lessepsian migration and tetrodotoxin poisoning due to Lagocephalus sceleratus in the eastern Mediterranean, Toxicon, 52, 964-968.

Botelho, M. J., Vale, C., Ferreira, J. G. (2015). Profiles of paralytic shellfish toxins in bivalves of low and elevated toxicities following exposure to Gymnodinium catenatum blooms in Portuguese estuarine and coastal waters. Chemosphere, 138, 1028-1036.

Burrell, S., Gunnarsson, T., Gunnarsson, K., Clarke, D., \& Turner, A. D. (2013). First detection of paralytic shellfish poisoning (PSP) toxins in Icelandic mussels (Mytilus edulis): Links to causative phytoplankton species. Food Control, 31(2), 295-301.

Cabanero, A.I., Madrid, Y., \& Camara, C. (2004). Selenium and mercury bioaccessibility in fish samples: an in vitro digestion method, Analytica Chimica Acta, 526, 51-61.

Cabanero, A.I., Madrid, Y., \& Camara, C. (2007). Mercury-selenium species ratio in representative fish samples and their bioaccessibility by an in vitro digestion method, Biological Trace Element Research, 119, 195-211. 
Cardoso, C., Afonso, C., Lourenço, H., Costa, S., \& Nunes, M.L. (2015). Bioaccessibility assessment methodologies and their consequences for the risk-benefit evaluation of food, Trends in Food Science and Technology, 41, 5-23.

Carmody, E.P., James, K.J., \& Kelly, S.S. (1996). Dinophysistoxin-2: the predominant diarrhoetic shellfish toxin in Ireland, Toxicon, 34, 351-359.

Canete, E., \& Diogene, J. (2008). Comparative study of the use of neuroblastoma cells (Neuro-2a) and neuroblastorna x glioma hybrid cells (NG108-15) for the toxic effect quantification of marine toxins, Toxicon, 52(4), 541-550.

Chen, J.H., Gao, L.Y., Li, Z.Y., Wang, S., Li, J.X., Cao, W., Sun, C.J., Zheng, L., \& Wang, X.R. (2016a). Simultaneous screening for lipophilic and hydrophilic toxins in marine harmful algae using a serially coupled reversed-phase and hydrophilic interaction liquid chromatography separation system with high-resolution mass spectrometry, Analytica Chimica Acta, 914, 117-126.

Chen, T.Y., Hsieh, C.H., \& Hwang, D.F. (2016b). Development of standardized methodology for identifying toxins in clinical samples and fish species associated with tetrodotoxin-borne poisoning incidents, Journal of Food and Drug Analysis, 24, 9-14.

Ching, P. K., Ramos, R. A., de los Reyes, V. C., Sucaldito, M. N., \& Tayag, E. (2015). Lethal paralytic shellfish poisoning from consumption of green mussel broth, Western Samar, Philippines, August 2013, Western Pacific Surveillance and Response Journal, 6(2), 22-26. 
Ciminiello, P., Dell'Aversano, C., Forino, M., \& Tartaglione, L. (2014). Marine Toxins in Italy: The More You Look, the More You Find, European Journal of Organic Chemistry, 7, 1357-1369.

Costa, P.R., Moita, T., \& Rodrigues, S.M. (2014). Estimating the contribution of Nsulfocarbamoyl paralytic shellfish toxin analogs GTX6 and C3p4 to the toxicity of mussels (Mytilus galloprovincialis) over a bloom of Gymnodinium catenatum, Harmful Algae, 31, 35-40.

Costa, P.R., Robertson, A., \& Quilliam, M.A. (2015). Toxin Profile of Gymnodinium catenatum (Dinophyceae) from the Portuguese Coast, as Determined by Liquid Chromatography Tandem Mass Spectrometry, Marine Drugs, 13, 2046-2062.

Costa, P. R., Costa, S. C., Braga, A. C., Rodrigues, S. M., \& Vale, P. (2017). Relevance and challenges in monitoring marine biotoxins in non-bivalve vectors, Food Control, 76, 24-33.

Deeds, J.R., Landsberg, J.H., Etheridge, S.M., Pitcher, G.C., \& Longan, S.W. (2008). Non-traditional vectors for paralytic shellfish poisoning, Marine Drugs, 6, 308-348.

Doucet, E., Ross, N. N., \& Quilliam, M. A. (2007). Enzymatic hydrolysis of esterified diarrhetic shellfish poisoning toxins and pectenotoxins. Analytical and Bioanalytical Chemistry, 389(1), 335-342. 
EFSA (2008a). Opinion of the Scientific Panel on Contaminants in the Food chain on a request from the European Comission on marine biotoxins in shellfish - okadaic acid and analogues, EFSA Journal, 589, 1-62.

EFSA (2008b). Opinion of the Scientific Panel on Contaminants in the Food chain on a request from the European Commission on marine biotoxins in shellfish - azaspiracids, EFSA Journal, 723,1-52.

EFSA (2009a). Opinion of the scientific panel on contaminants in the food chain on a request from the European Commission on marine biotoxins in shellfish - domoic acid, EFSA Journal, 1181, 1- 61.

EFSA (2009b). Scientific opinion of the panel on contaminants in the food chain on a request from the European Commission on marine biotoxins in shellfish - saxitoxin group, EFSA Journal, 1019, 1-76.

EFSA (2010). Scientific opinion on marine biotoxins in shellfish - emerging toxins: the brevetoxin group, EFSA Journal, 8(7), 1677.

EFSA (2017). Risks for public health related to the presence of tetrodotoxin (TTX) and TTX analogues in marine bivalves and gastropods, EFSA Journal, 15 (4), 4752.

Etheridge, S. M. (2010). Paralytic shellfish poisoning: seafood safety and human health perspectives, Toxicon, 56(2), 108-122. 
EURLMB (2008). EU-harmonised Standard Operating Procedure for Determination of Domoic Acid in Shellfish and Finfish by RP-HPLC using UV Detection.

EURLMB (2015). EU-Harmonised Standard Operating Procedure for determination of Lipophilic marine biotoxins in molluscs by LC-MS/MS.

European Commission, 2004a. Regulation (EC)No 854/2004 of the European Parliament and of the council of 29 april 2004 laying down specific rules for the organization of official controls on products of animal origin intended for human consumption. Off. J. Eur. Union. L226, 83-127.

European Commission, 2004b. Regulation (EC)No 853/2004 of the European Parliament and of the council of 29 april 2004 laying down specific hygiene rules for food of animal origin. Off. J. Eur. Union. L139, 22-82.

Fernandez-Ortega, J. F., Morales-de los Santos, J. M., Herrera-Gutierrez, M. E., Fernandez-Sanchez, V., Rodriguez Loureo, P., Rancano, A. A., \& Tellez-Andrade, A. (2010). Seafood intoxication by tetrodotoxin: first case in Europe, The Journal of Emergency Medicine, 39(5), 612-617.

Ferreiro, S.F., Carrera, C., Vilarino, N., Louzao, M.C., Santamarina, G., Cantalapiedra, A.G., \& Botana, L.M. (2015). Acute Cardiotoxicity Evaluation of the Marine Biotoxins OA, DTX-1 and YTX, Toxins 7, 1030-1047. 
Garcia, C., del Carmen Bravo, M., Lagos, M., \& Lagos, N. (2004). Paralytic shellfish poisoning: post-mortem analysis of tissue and body fluid samples from human victims in the Patagonia fjords, Toxicon, 43(2), 149-158.

Garcia, C., Barriga, A., Diaz, J. C., Lagos, M., \& Lagos, N. (2010). Route of metabolization and detoxication of paralytic shellfish toxins in humans, Toxicon, 55(1), $135-144$

Garcia, C., Rodriguez-Navarro, A., Diaz, J. C., Torres, R., \& Lagos, N. (2009). Evidence of in vitro glucuronidation and enzymatic transformation of paralytic shellfish toxins by healthy human liver microsomes fraction, Toxicon, 53(2), 206-213.

García-Altares, M., Diogène, J., \& de la Iglesia, P. (2013). The implementation of liquid chromatography tándem mass spectrometry for the oficial control of lipophilic toxins in seafood: Single-laboratory validation under four chromatographic conditions. J. Chromatogr. A 1275 (2013) 48-60.

Gerssen, A., Pol-Hofstad, I.E., Poelman, M., Mulder, P.P.J., van den Top, H.J., \& de Boer, J. (2010). Marine Toxins: Chemistry, Toxicity, Occurrence and Detection, with Special Reference to the Dutch Situation, Toxins, 2, 878-904.

Gerssen, A., Bovee, T. H. F., Klijnstra, M. D., Poelman, M., Portier, L., \& Hoogenboom, L. A. P. (2018). First Report on the Occurrence of Tetrodotoxins in Bivalve Mollusks in The Netherlands, Toxins 2018, 10(11), 450. 
Geraghty, J., Duffy, C., Bunæs, J. A. A., Hess, P., \& Foley, B. (2014). In vivo study of azaspiracids in mini pigs. Toxicon, 91, 172-173.

Hess, P., Nguyen, L., Aasen, J., Keogh, M., Kilcoyne, J., McCarron, P., \& Aune, T. (2005). Tissue distribution, effects of cooking and parameters affecting the extraction of azaspiracids from mussels, Mytilus edulis, prior to analysis by liquid chromatography coupled to mass spectrometry, Toxicon, 46(1), 62-71.

How, C.K., Chern, C.H., Huang, Y.C., Wang, L.M., \& Lee, C.H. (2003). Tetrodotoxin poisoning. American Journal of Emergency Medicine, 21, 51-54.

James, K. J., Furey, A., Lehane, M., Ramstad, H., Aune, T., Hovgaard, P., Morris, S., Higman, W., Satake, M., \& Yasumoto, T. (2002). First evidence of an extensive northern European distribution of azaspiracid poisoning (AZP) toxins in shellfish, Toxicon, 40(7), 909-915.

James, K. J., Gillman, M., Amandi, M. F., Lopez-Rivera, A., Puente, P. F., Lehane, M., Mitrovic, S., \& Furey, A. (2005). Amnesic shellfish poisoning toxins in bivalve molluscs in Ireland, Toxicon, 46(8), 852-858.

Jang, J., \& Yotsu-Yamashita, M. (2006). Distribution of tetrodotoxin, saxitoxin, and their analogs among tissues of the puffer fish Fugu pardalis, Toxicon, 48(8), 980-987.

Jang, J. H., Lee, J. S., \& Yotsu-Yamashita, M. (2010). LC/MS analysis of tetrodotoxin and its deoxy analogs in the marine puffer fish Fugu niphobles from the southern coast 
of Korea, and in the brackishwater puffer fishes Tetraodon nigroviridis and Tetraodon biocellatus from Southeast Asia, Marine Drugs, 8(4), 1049-1058.

Jauffrais, T., Kilcoyne, J., Herrenknecht, C., Truquet, P., Sechet, V., Miles, C.O., \& Hess, P. (2013). Dissolved azaspiracids are absorbed and metabolized by blue mussels (Mytilus edulis), Toxicon, 65, 81-89.

Johnson, S., Harrison, K., \& Turner, A. D. (2016). Application of rapid test kits for the determination of Diarrhetic Shellfish Poisoning (DSP) toxins in bivalve molluscs from Great Britain, Toxicon, 111, 121-129.

Jorgensen, K., Scanlon, S., \& Jensen, L. B. (2005). Diarrhetic shellfish poisoning toxin esters in Danish blue mussels and surf clams, Food Additives \& Contaminants, 22(8), 743-751.

Lee, C.H., Ruben, P.C. (2008). Interaction between voltage-gated sodium channels and the neurotoxin, tetrodotoxin, Channels, 2, 407-412.

Lee, J.S., Igarashi, T., Fraga, S., Dahl, E., Hovgaard, P., \& Yasumotol, T. (1989). Determination of diarrhetic shellfish toxins in various dinoflagellate species, Journal of Applied Phycology, 1, 147-152.

Kilcoyne, J., Jauffrais, T., Twiner, M.J., Doucette, G.J., Aasen, J.A., Sosa, S., Krock, B., Séchet, V., Nulty, C., Salas, R., Clarke, D., Geraghty, J., Duffy, C., Foley, B., John, U., Quilliam, M.A., McCarron, P., Miles, C.O., Silke, J., Cembella, A., Tillmann, U., Hess, 
P. (2014). Azaspiracids-Toxicological Evaluation, Test Methods and Identification of the Source Organisms (ASTOX II). Technical Report. Marine Institute, Galway, Ireland (ISSN:2009-3195. 188 pp).

MacKenzie, A. L. (2014). The risk to New Zealand shellfish aquaculture from paralytic shellfish poisoning (PSP) toxins, New Zealand Journal of Marine and Freshwater Research, 48(3), 430-465.

Manita, D., Alves, R.N., Braga, A.C., Fogaca, F.H., Marques, A., \& Costa, P.R. (2017). In vitro bioaccessibility of the marine biotoxins okadaic acid, dinophysistoxin- 2 and their 7-O-acyl fatty acid ester derivatives in raw and steamed shellfish, Food and Chemical and Toxicology, 101, 121-127.

Marques, A., Lourenco, H.M., Nunes, M.L., Roseiro, C., Santos, C., Barranco, A., Rainieri, S., Langerholc, T., \& Cencic, A. (2011). New tools to assess toxicity, bioaccessibility and uptake of chemical contaminants in meat and seafood, Food Research International, 44, 510-522.

Marr, J.C., Hu, T., Pleasance, S., Quilliam, M.A., \& Wright, J.L.C. (1992). Detection of New 7-0-Acyl Derivatives of Diarrhetic Shellfish Poisoning Toxins by LiquidChromatography Mass-Spectrometry, Toxicon, 30, 1621-1630.

Maulvault, A.L., Machado, R., Afonso, C., Lourenco, H.M., Nunes, M.L., Coelho, I., Langerholc, T., \& Marques, A. (2011). Bioaccessibility of $\mathrm{Hg}, \mathrm{Cd}$ and As in cooked black scabbard fish and edible crab, Food and Chemical Toxicology, 49, 2808-2815. 
McNamee, S. E., Medlin, L. K., Kegel, J., McCoy, G. R., Raine, R., Barra, L., Ruggiero, M. V., Kooistra, W. H., Montresor, M., Hagstrom, J., Blanco, E. P., Graneli, E., Rodriguez, F., Escalera, L., Reguera, B., Dittami, S., Edvardsen, B., Taylor, J., Lewis, J. M., Pazos, Y., Elliott, C. T., \& Campbell, K. (2016). Distribution, occurrence and biotoxin composition of the main shellfish toxin producing microalgae within European waters: A comparison of methods of analysis, Harmful Algae, 55, 112-120.

Moita, M.T., Pazos, Y., Rocha, C., Nolasco, R., \& Oliveira, P.B. (2016). Toward predicting Dinophysis blooms off NW Iberia: A decade of events, Harmful Algae, 53, 17-32.

Morono, A., Arevalo, F., Fernandez, M.L., Maneiro, J., Pazos, Y., Salgado, C., \& Blanco, J. (2003). Accumulation and transformation of DSP toxins in mussels Mytilus galloprovincialis during a toxic episode caused by Dinophysis acuminata. Aquatic Toxicology, 62, 269-280.

Murk, A. J., Nicolas, J., Smulders, F. J. M., Bürk, C., Gerssen, A. Marine biotoxins: types of poisoning, underlying mechanisms of action and risk management programmes, in: Smulders, F. J. M., Rietjens, I.M.C.M., and Rose, M. (Eds.), Food safety assurance and veterinary public health - volume 7 - Chemical hazards in foods of animal origin, Wageningen Academic Publishers, The Netherlands, 2019, pp. 208-209. 
Nakashima, K., Arakawa, O., Taniyama, S., Nonaka, M., Takatani, T., Yamamori, K., Fuchi, Y., \& Noguchi, T. (2004). Occurrence of saxitoxins as a major toxin in the ovary of a marine puffer Arothron firmamentum, Toxicon, 43, 207-212.

Negri, A. P., Bolch, C. J. S., Geier, S., Green, D. H., Park, T. G., \& Blackburn, S. I. (2007). Widespread presence of hydrophobic paralytic shellfish toxins in Gymnodinium catenatum, Harmful Algae, 6(6), 774-780.

Ngy, L., Tada, K., Yu, C.F., Takatani, T., \& Arakawa, O. (2008). Occurrence of paralytic shellfish toxins in Cambodian Mekong pufferfish Tetraodon turgidus: selective toxin accumulation in the skin, Toxicon, 51, 280-288.

Noguchi, T. \& Ebesu, J. S. (2001). Puffer poisoning: epidemiology and treatment, Journal of Toxicology: Toxin Reviews, 20, 1-10.

Nzoughet, J.K., Campbell, K., Barnes, P., Cooper, K.M., Chevallier, O.P., \& Elliott, C.T. (2013). Comparison of sample preparation methods, validation of an UPLC-MS/MS procedure for the quantification of tetrodotoxin present in marine gastropods and analysis of pufferfish, Food Chemistry, 136, 1584-1589.

Oshima, Y., Blackburn, S.I., \& Hallegraeff, G.M. (1993). Comparative-Study on Paralytic Shellfish Toxin Profiles of the Dinoflagellate Gymnodinium catenatum from 3 Different Countries, Marine Biology, 116, 471-476. 
Paredes, I., Rietjens, I.M., Vieites, J.M., \& Cabado, A.G. (2011). Update of risk assessments of main marine biotoxins in the European Union. Toxicon, 58, 336-354.

Percopo, I., Siano, R., Rossi, R., Soprano, V., Sarno, D., \& Zingone, A. (2013). A new potentially toxic Azadinium species (Dinophyceae) from the Mediterranean Sea, A. dexteroporum sp. Nov, Journal of phycology, 49, 950-966.

Pulido, O.M. (2008). Domoic acid toxicologic pathology: A review, Marine Drugs 6, 180219.

Quilliam, M.A., \& Wright, J.L.C. (1989). The Amnesic Shellfish Poisoning Mystery, Analytical Chemistry, 61, 1053A-1060A.

Rambla-Alegre M., Reverté L., del Río V., de la Iglesia P., Palacios O., Flores C., Caixach J., Campbell K., Elliott C.T., Izquierdo-Muñoz A., Campàs M., \& Diogène J. (2017). Evaluation of tetrodotoxins in puffer fish caught along the Mediterranean coast of Spain. Toxin profile of Lagocephalus sceleratus, Environmental Research, 158, 1-6.

Regueiro, J., Rossignoli, A. E., Alvarez, G., \& Blanco, J. (2011). Automated on-line solid-phase extraction coupled to liquid chromatography-tandem mass spectrometry for determination of lipophilic marine toxins in shellfish, Food Chemistry, 129(2), 533-540.

Reverté L., de la Iglesia P., del Río V., Campbell K., Elliott C.T., Kawatsu K., Katikou P., Diogène J., \& Campàs M. (2015). Detection of tetrodotoxins in puffer fish by a self- 
assembled monolayer-based immunoassay and comparison with surface plasmon resonance, LC-MS/MS and mouse bioassay, Analytical Chemistry, 87, 10839-10847.

Rodriguez, L.P., Gonzalez, V., Martinez, A., Paz, B., Lago, J., Cordeiro, V., Blanco, L., Vieites, J.M., \& Cabado, A.G. (2015). Occurrence of Lipophilic Marine Toxins in Shellfish from Galicia (NW of Spain) and Synergies among Them, Marine Drugs, 13, $1666-1687$.

Rodriguez, P., Alfonso, A., Otero, P., Katikou, P., Georgantelis, D., \& Botana, L.M. (2012). Liquid chromatography-mass spectrometry method to detect Tetrodotoxin and Its analogues in the puffer fish Lagocephalus sceleratus (Gmelin, 1789) from European waters, Food Chemistry, 132, 1103-1111.

Rossignoli, A. E., Fernandez, D., Regueiro, J., Marino, C., \& Blanco, J. (2011). Esterification of okadaic acid in the mussel Mytilus galloprovincialis, Toxicon, 57(5), $712-720$.

Salas, R., Tillmann, U., John, U., Kilcoyne, J., Burson, A., Cantwell, C., Hess, P., Jauffrais, T., \& Silke, J. (2011). The role of Azadinium spinosum (Dinophyceae) in the production of azaspiracid shellfish poisoning in mussels, Harmful Algae, 10, 774-783.

Silva, M., Azevedo, J., Rodriguez, P., Alfonso, A., Botana, L.M., \& Vasconcelos, V. (2012). New Gastropod Vectors and Tetrodotoxin Potential Expansion in Temperate Waters of the Atlantic Ocean, Marine Drugs, 10, 712-726. 
Tillmann, U., Elbrachter, M., John, U., Krock, B., \& Cembrella, A. (2010). Azadinium obesum (Dinophyceae), a new nontoxic species in the genus that can produce azaspiracid toxins, Phycologia, 49, 169-182.

Torgersen, T., Wilkins, A.L., Rundberget, T., \& Miles, C.O. (2008). Characterization of fatty acid esters of okadaic acid and related toxins in blue mussels (Mytilus edulis) from Norway, Rapid Communications in Mass Spectrometry, 22, 1127-1136.

Toyofuku, H. (2006). Joint FAO/WHO/IOC activities to provide scientific advice on marine biotoxins (research report), Marine Pollution Bulletin, 52, 1735-1745.

Turner, A. D., \& Goya, A. B. (2015). Occurrence and profiles of lipophilic toxins in shellfish harvested from Argentina, Toxicon, 102, 32-42.

Twiner, M. J., Rehmann, N., Hess, P., \& Doucette, G. J. (2008). Azaspiracid shellfish poisoning: a review on the chemistry, ecology, and toxicology with an emphasis on human health impacts, Marine Drugs, 6(2), 39-72.

Ujevic, I., Nincevic-Gladan, Z., Roje, R., Skejic, S., Arapov, J., \& Marasovic, I. (2010). Domoic Acid - A New Toxin in the Croatian Adriatic Shellfish Toxin Profile, Molecules, 15(10), 6835-6849.

Valdiglesias, V., Prego-Faraldo, M.V., Pasaro, E., Mendez, J., \& Laffon, B. (2013). Okadaic Acid: More than a Diarrheic Toxin, Marine Drugs, 11, 4328-4349. 
Vale, P., \& Sampayo, M. A. (2001). Domoic acid in Portuguese shellfish and fish, Toxicon, 39(6), 893-904.

Vale, P., \& Sampayo, M.A. (2002a). Esterification of DSP toxins by Portuguese bivalves from the Northwest coast determined by LC-MS--a widespread phenomenon, Toxicon, $40,33-42$

Vale, P., \& Sampayo, M.A.D. (2002b). First confirmation of human diarrhoeic poisonings by okadaic acid esters after ingestion of razor clams (Solen marginatus) and green crabs (Carcinus maenas) in Aveiro lagoon, Portugal and detection of okadaic acid esters in phytoplankton. Toxicon, 40, 989-996.

Vale, C., \& Botana, L.M. (2008). Marine toxins and the cytoskeleton: okadaic acid and dinophysistoxins, The FEBS journal 275, 6060-6066.

Vale, P., Bire, R., \& Hess, P. (2008). Confirmation by LC-MS/MS of azaspiracids in shellfish from the Portuguese north-western coast, Toxicon, 51, 1449-1456.

Versantvoort, C.H.M., Oomen, A.G., Van de Kamp, E., Rompelberg, C.J.M., \& Sips, A.J.A.M. (2005). Applicability of an in vitro digestion model in assessing the bioaccessibility of mycotoxins from food, Food and Chemical Toxicology, 43, 31-40.

Villar-Gonzalez, A., Rodriguez-Velasco, M. L., Ben-Gigirey, B., \& Botana, L. M. (2007). Lipophilic toxin profile in Galicia (Spain): 2005 toxic episode, Toxicon, 49(8), 11291134. 
Visciano, P., Schirone, M., Berti, M., Milandri, A., Tofalo, R., \& Suzzi, G. (2016). Marine Biotoxins: Occurrence, Toxicity, Regulatory Limits and Reference Methods, Frontiers in microbiology, 7, 1051.

Walker, J.R., Novick, P.A., Parsons, W.H., McGregor, M., Zablocki, J., Pande, V.S., Du Bois, J. (2012). Marked difference in saxitoxin and tetrodotoxin affinity for the human nociceptive voltage-gated sodium channel (Nav1.7). Proc. Natl. Acad. Sci. USA, 109, $18102-18107$.

Wiese, M., D'Agostino, P.M., Mihali, T.K., Moffitt, M.C., \& Neilan, B.A. (2010). Neurotoxic Alkaloids: Saxitoxin and Its Analogs, Marine Drugs, 8, 2185-2211.

Wu, H.Y., Yao, J.H., Guo, M.M., Tan, Z.J., Zhou, D.Q., \& Zhai, Y.X. (2015). Distribution of Marine Lipophilic Toxins in Shellfish Products Collected from the Chinese Market, Marine Drugs, 13, 4281-4295.

Yasumoto, T., Murata, M., Oshima, Y., Sano, M., Matsumoto, G. K., \& Cardy, J. (1985). Diarrhetic Shellfish Toxins, Tetrahedron Letters, 41(6), 1019-1025.

Yotsu-Yamashita M., Yamagishi Y., \& Yasumoto T. (1995). 5,6,11-trideoxytetrodotoxin from the puffer fish, Fugu poecilonotus, Tetrahedron Letters, 36, 9329-9332. 
Yotsu-Yamashita, M., Mebs, D., Kwet, A., \& Schneider, M. (2007). Tetrodotoxin and its analogue 6-epitetrodotoxin in newts (Triturus spp.; Urodela, Salamandridae) from southern Germany, Toxicon, 50(2), 306-309.

Yotsu-Yamashita, M. Abe Y., Kudo Y., Ritson-Williams R., Paul V.J., Konoki K., Cho Y., Adachi M., Imazu T., Nishikawa T., \& Isobe M. (2013). First identification of 5,11dideoxytetrodotoxin in marine animals, and characterization of major fragment ions of tetrodotoxin and its analogs by high resolution ESI-MS/MS, Marine Drugs, 11, 27992813.

Zamorano, R., Marin, M., Cabrera, F., Figueroa, D., Contreras, C., Barriga, A., Lagos, N., \& Garcia, C. (2013). Determination of the variability of both hydrophilic and lipophilic toxins in endemic wild bivalves and carnivorous gastropods from the Southern part of Chile. Food Additives and Contaminants Part A - Chemistry Analysis Control Exposure \& Risk Assessment, 30(9), 1660-1677.

Zingone, A., \& Enevoldsen, H.O. (2000). The diversity of harmful algal blooms: a challenge for science and management, Ocean \& Coastal Management, 43, 725-748. 